\title{
DISF" IIMER
}

\begin{abstract}
This roport wee prepared an an ecoount of work sponeored by an agency of the United States Covernment. Nittber the Ualted Stutes Gomernment mor any apacy thereof, not any of thelr

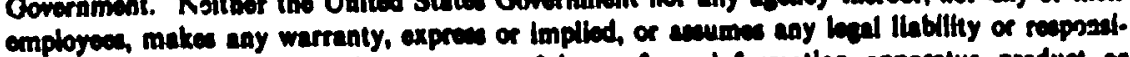

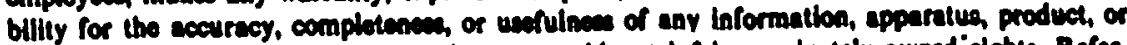

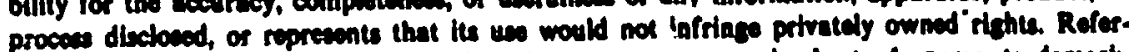

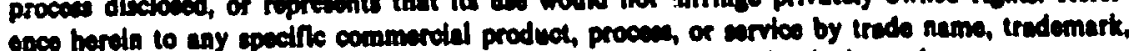

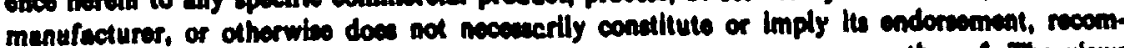
mendation, of favortas by the United Stutes Coverameat of any agancy thereof. The vowe

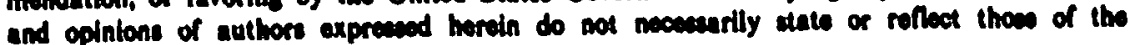
United States Covernment of any apency thereof.
\end{abstract}

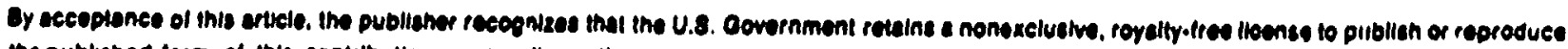

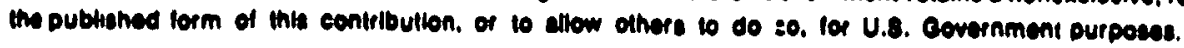

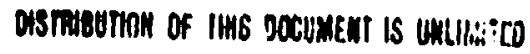

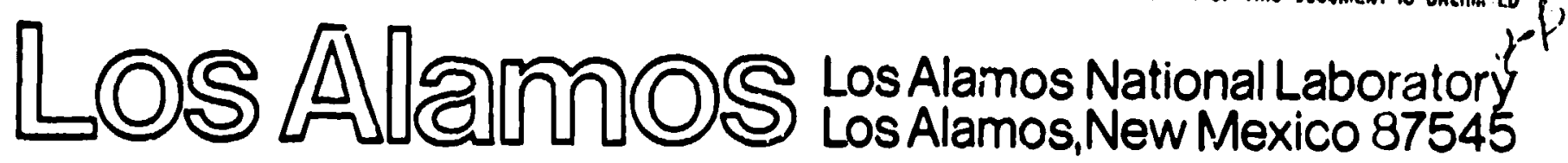


LONG TERY OBSERVATIONS OF CYG X-3 WITH VELA 5B

\author{
W. Priedhorsky \\ Los Al amos Natlonal Laboratory \\ LO8 Al amo8, New Mexico 87545
}

ABSTRACT. We present 1ong-term (1969-1979) observations of Cygnus $X-3$, obtalned by the Vela 58 satell1te. The 3-12 keV l1ght curve has 10 day time resolution. Cyg $X-3$ is a peculiar high-luminosity $X$-ray source, radiating from the rad10 reglon to hard gemana rays of more than $10^{16} \mathrm{ev}$. It has a 4.8 hour per1od, probably orbltal, which 18 not resolved by our present analys1s. Long term perlodicltlee of 17, 20, and 33-34 days have been reported by several authors, and explained as the effects of apsidul motion, precession, or an eccentric orb1t. We do not observe the 17 and 33-34 day varlations, and set upper 11mits elgnificanty lower than the reported amplitude of the 33-34 day varlation. There 1 s weak avidence for a 20 day flux varlat 1on. The $11 \mathrm{ght}$ curve show h1gh and low states which alternate with a characterlatic timescale of $\sim 1$ year. There 18 no cnunterpart, at th1s time resolution, of the glant red10 outburst of 1972 September.

\title{
I. INTRODUCTION
}

Cyg X-3 18 unlque Calact1c obfect. Though distant, 1t 1s one of the brfghtest objects in the oky in soveral band ranging from the rad 10 to $10^{16}$ oV gema rays. Cyg $X-3$ behaves 11ke a falriy normal X-ray b1nary in the X-ray band, but 1te emiselon at other wevelengthe ouggests 1t may not be one. In an $x$-ray blnery model there are roselble long-terr: perlodic varlations which could te earched for with long-term monitoring Inatruments. Apoldal notion in the Cyg $x-3$ eyotem could have perlode from rmeks (for a maln equence compan1on) to ndecades (for a hellum-etar companion; Ghosh et al. 1981). DI ak preceselon, at observed In eeveral $X$-ray blnacles, could have a perlod 1 n the range of a few daye to a few weeks. Finally, there 1s the poselbillty that the 4.8 hour $X$-ray perlod 1s not the orbltal period, and the true, longer perlod would be ev1denced by Doppler phase verlatione or en overall flux varlation (erpecially for an eccentric orb1t).

Long-term perlodic varlatione have Indeed been reported for Cys $X-3$. The Arlel 5 All-Sky Mondtor (ASTS) prov1ded 3-6 kaV coverage over the per1od 1974-1979; analye1s of theee data euggested a per1odsc variation. Th1s we E1rat reported a a 16.73-day flux varsation (Holt 
et al. 1976), while Holt et al. (1979) refined the perlod to $33.0 \pm 0.2$ Jays. Noltenl et al. $(1 \overline{980})$ reported $34.1 \pm 0.1$ day flux variation,

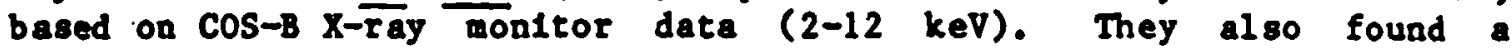
variation in the phase of 4.8 hour minimum, which they ascribed to Doppler motion; these effects were explained by postulating a 34.1 day orbital motion for the syotem. Dolan et al. (1982) reported a possible correlation of the 23-73 keV pulsed fraction with the 34.1 day perfod. Dowthwate et al. (1983) found that positive detectlons at $10^{12} \mathrm{eV}$ tended to be correlated with the 34.1 day perlod. However, analysis of nore extensive COS-B data by Bonnet-BIdaud and van der K118 (1981) showed no strong Increase in flux at the predicted 34.1 day maximum. The phase of alninum of thelr 4.8 hour 11ght curves varied in a fashion consistent with apsidal motion in a sightly eccentric orbit of period $\sim 20$ daye.

\section{VELA OBSERVATIONS}

A small scintillator-photomult1plier detector on the Vela 5B satell1te provided scanning 3-12 keV all-sky coverage for the perlod 1969-1979 with incomplete data acquisition after 1976. Sources were observed for 1 e each 64 s satell1te opin perlod for about 2-3 hours out of each 56 hour scan cycle. Data are summed Inco 10-day sky maps from which Individual source historles can be calculafed. Sensitivity of the Instrument was 1 imlted by 1 te emall area $\left(27 \mathrm{~cm}^{2}\right)$ and also by 1 ts h1gh background, which averaged $0.8 \mathrm{Crab}$. The experiment and analyo1s technique are dlecuseed in more detall in Terrell et al. (1982) and Prledhoraky, Terrell, and Holt (1983).

P1gure 1 ahows the 1969-1976 time h1story of Cyg $x-3$. One Vela count -1 corresponds to $4.5 \times 10^{-10}$ erg $\mathrm{cm}^{-2} \mathrm{e}^{-1}$ in the $3-12 \mathrm{keV}$ band for Crab-11ke spectrum. The Crab nebula gives 40 Vela counts $8^{-1}$. The vela data are compered in figure 2 to overlapping Ariel 5 ASM observatione (Holt et al. 1979; Holt private communicetion). The agreement is good; the two 1975 outbus te and the 1976 minimum were observed by both instruments.

\section{ANALYSIS}

P1gute 1 suggeets a two-state behav1or for Cyg $x-3$, with rap1d step-like changen between high and low levels. Figure 3 chows a hletogran of $\mathrm{Gy} x-3$ count rate ve. occurrences (number of 10-day bins with a given count rate). The histogrem showe a broad diatribution of flux levele, wth only a hint of blmodality. Th1s is consietent with F1gure 1, where $1 t$ can be ceen that there 1o a wde varlation in the flux level within the high and lov stutes. Datalled opectral analyols

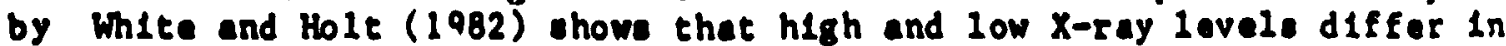
X-ray Iuminostey. S1nce the $x$-ray emiesion dominates the bolometric output of thle cyotem, the change of state eppeare to reflact a change In the rate of energy converaion in the "central engine" of this object. 


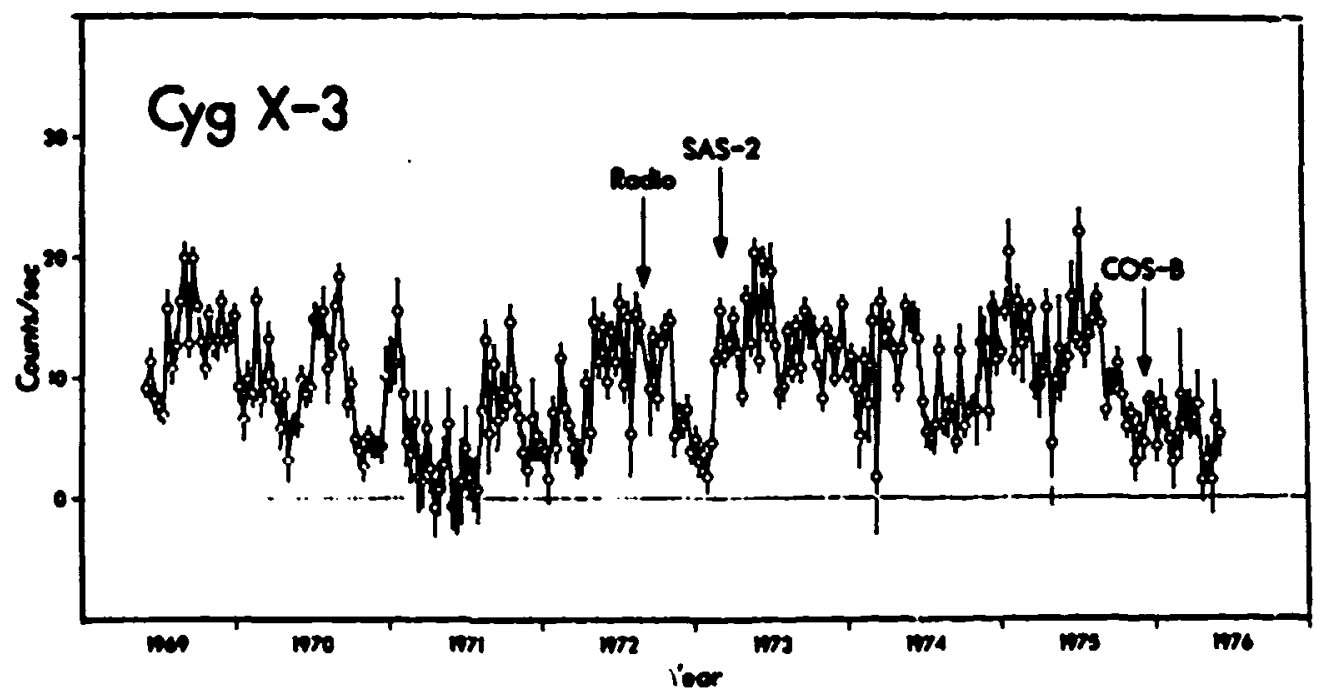

Figure 1. 3-12 keV flux h1story of Cyg X-3, in 10-day averages, from the Vela jB satellite. Arrows nark the glant radlo outburst of 1972 Septenber, and the 1973 SAS-2 and 1975 COS-B gama observations.

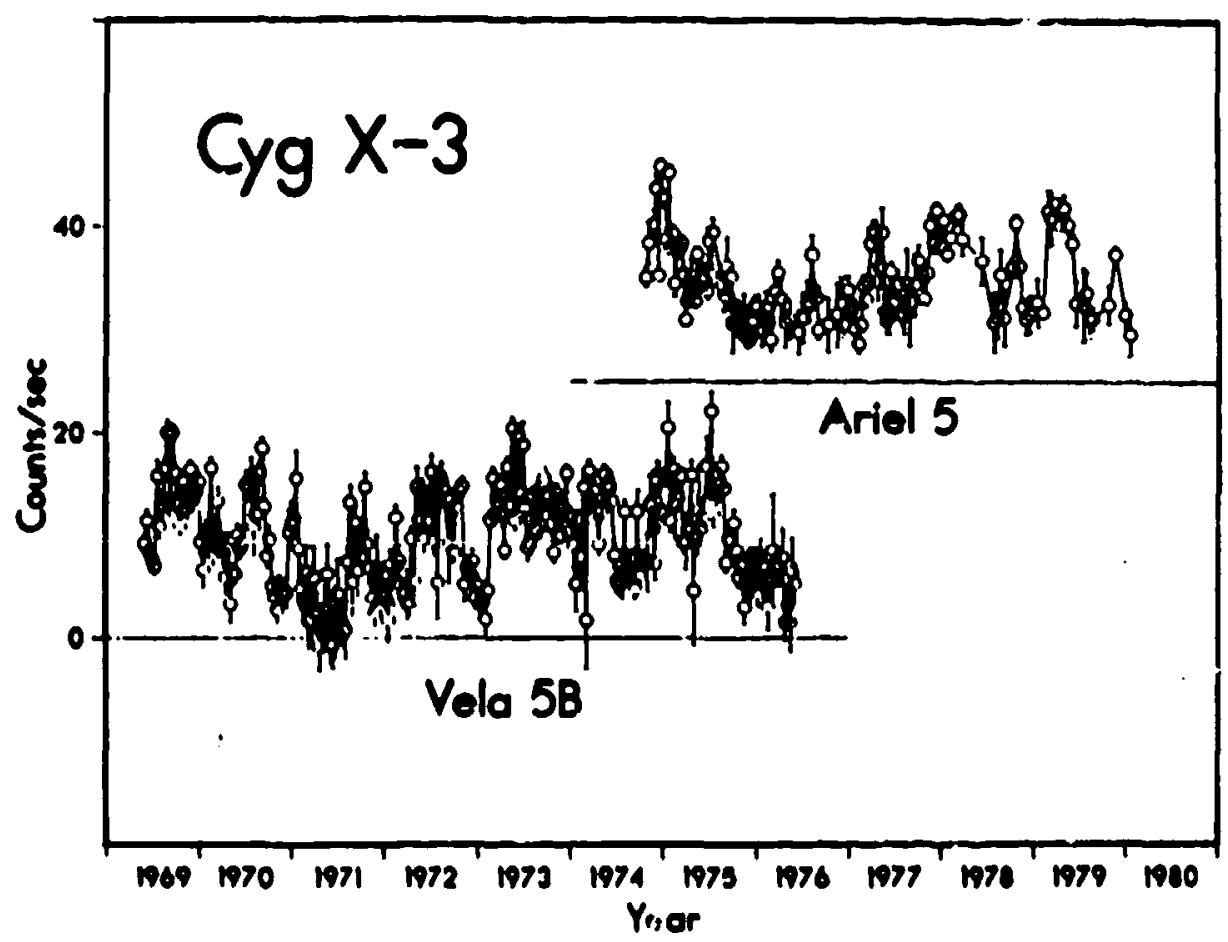

F1gure 2. Comparicon of the 3-12 keV Vela 5B and 3-6 keV Ariel 5 enecurcente of Cyg $X-3$. The Arlel 3 polnte (3-6 kev photone $\mathrm{cm}^{-2},-1$ ) heve been ecaled by a factor of 40 , in the ratio of the mean elgnals, to allow comparison on the sane flgure. 


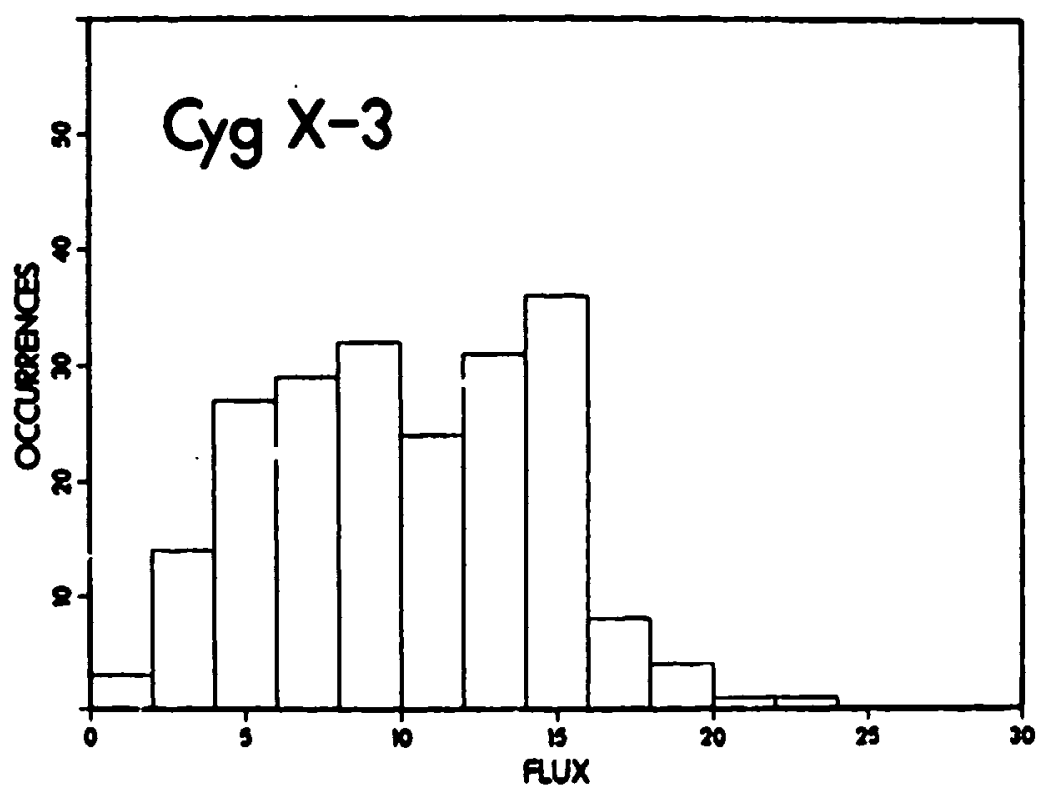

F1gure 3. H1stogran of Vela count rates from Cyg $x-3$. The ordinate Indicates the number of 10-day averages with moan flux in each bin.

The long-term variation in flux level can be explained by a change in the accretion rate of a compact object, but is more difficult to explain in a pulsar wodel where the energy source 18 internal to the compact object.

The time of the 1972 glant rad10 outburst 18 marked on flgure 1 . There 18 no unusual varlation in the $X$-ray flux correlated with this event, et least on tiacecales of $\sim 10$ days. This 18 conslatent with the unremarkable $X$-ray buhavlor observed by Uhuru around the time of outburst (Parsignault at al. 1972). Also indicated 1s the tlme of the raported SAS-2 $100 \mathrm{MeV}$ detection (Lamb et al. 1977). The source wee in an X-ray high etate at the t1me, wh1le $1 t$ was $1 \mathrm{n}$ a low state during the cos-B observation, of 1975 Deceaber, 1977 June, and 1978 November (Swanenburg et al. 1981). Th1.e might explain the diecrepancy between the 8As-2 and Cos-B observatione; however, there 1 s reaso: to belleve that nost. of the excese flux reported by SAS-2 was diffuse gamme radiation from gas and dust in the Cygnus arm (Hermeen 1985).

Three eete of data were Fourler analyeed to eearch for perlodic varlation: the complate eet, and oubsete chocen to eegrugate high otate and low etate data. Man fluxes for the h1gh and low otates, and the total date set, were $13,0,5.3$, and 10.4 vela counte -1 . The traneforme are plotted in flgure 4. The 1rregular traneltione between etatee are represented in the "all" transform as excese Fourler power at 


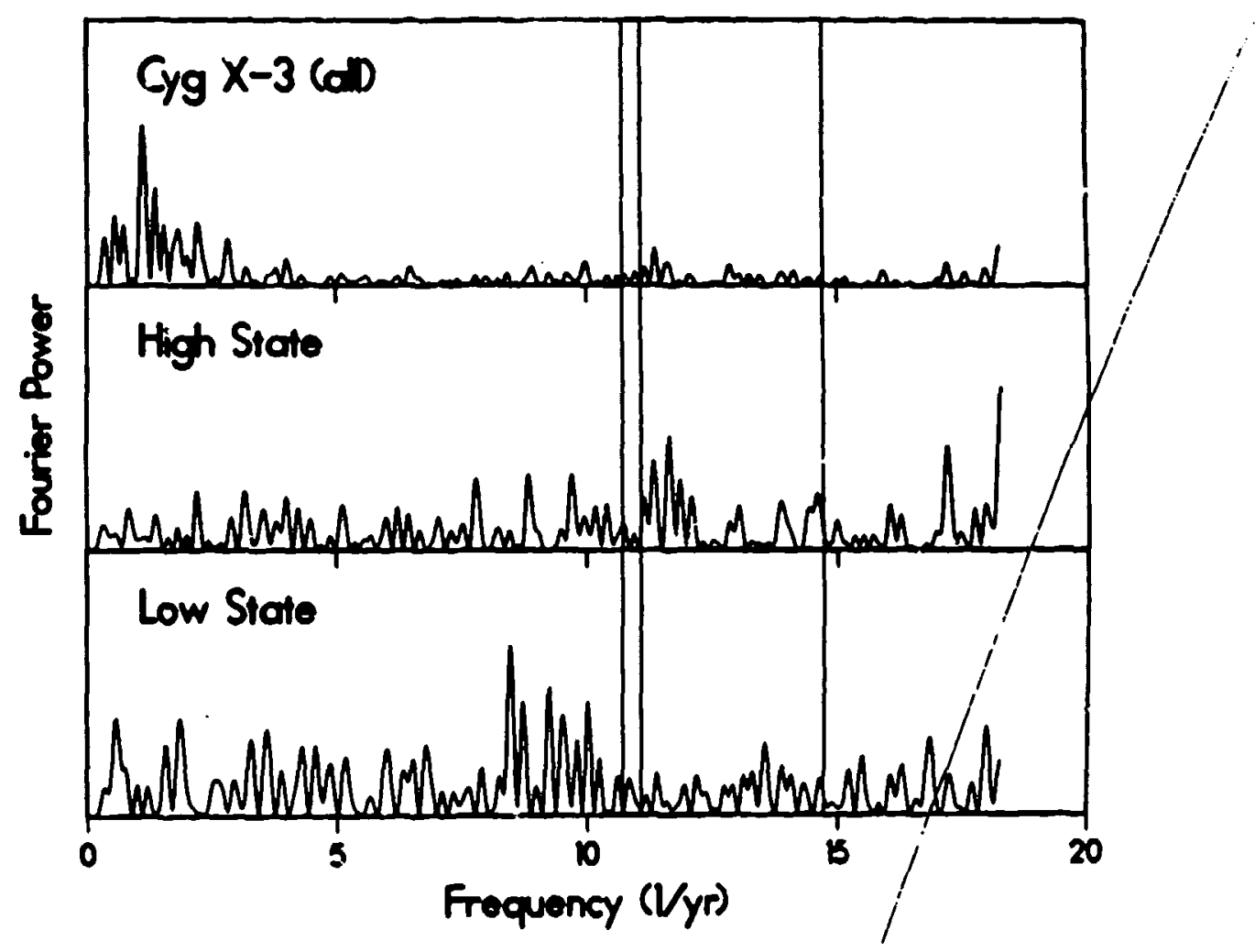

F1gure 4. Fourler transform of Cyg X-3 data. The three data sete Include all the data, selected high etate data, and selected low otate data. The vertical ines indicate previousiy reported periode of 34.1, 33.0 , and 16.75 days (allased in this analya18)

periode of $1 / 2$ to 2 yeare. There 1s no coherence to th1 var1ation: anslyale of the Arlel 5 ASM data (Holt, private comunlcation) how excess power in the oame frequency range; hatrever, the peaks are not at the same frequencles.

Prevlously reported perlode of $34.1,33.0$, and 16.75 days are Indicated in the elgure (10.71, 11.07, and 14.72 (ailased) cycles $\mathrm{yr}^{-1}$ ). There 1o no elgnificant varietion at any of these frequencies. At 33 and 34.1 deye, the 20 11mite on the puleed amplitude are 11x, 16\%, and 97 for the high, low, and complete date ete. Thlo compares to aoplitudes of $13 \%$ and $55 \%$ reported by Holt at al. (1979) and Moltenl et 1. (1980) reepectively. The 33 or 34.1 day perlode, if real, are not alwaye present at the reported amplitudes. We are laes censitive to a 16.75 day perlod. The vele $11 \operatorname{lol}$ te $(2 \sigma)$ are $22 x, 33 \%$, and $19 \%$, not axall unough to rule out the publlahed $11 \mathrm{ght}$ curve (Holt at al.) which had a 16.75 day asplitude of $18 \%$. 
Two perlods are suggested at low significance. There 18 a peak in the high state transform consistent with the Nyquist frequency, at 18.26 \pm 0.03 cycles $\mathrm{yr}^{-1}(20$ dags $)$. Desplte the suspic1ous frequency, it could not be duplicated in sinulations which scrambled the data (with the sane sampling), and does not appear in analysis of any other Vela source. Its proximity to the perilod reported by Bonnet-Bidaud and van der Klis (1981) is intriguing; the chance of it appearing randomly in the perlod range $20 \pm 2$ days 18 only $0.7 \%$. If real, it corresponds to a pulsed amplitude greater than 7\%. The 11-year time history (figure 2) sisows flux minlma in late 1971 and jate 1976, and broad maxima in 1969 , 1973-1974, and 1978-1979. Th18 suggests a very 1ong-term ( 5 years) cycle which could only be confirmed by more long-term monitoring.

\section{CONCLUSIONS}

Data from the Vela 5B satellite allow a unique long look at the fli: history of $\mathrm{Cyg} X-3$. Irregular transitions between high and low levels take place on a timescale of $1 / 2--2$ years. There are no 8 igniflcant perlodic varlations with perlods greater than 20 days. Prevlously reported 33 and 34.1 day varlatlons are not conitrmed. The $\sim 20$ day perlodic phese shlft reported by Bonnet-Bldaud and van der $\mathrm{Kils}$ (1981) cannot be ruled out; In fact, there 1s wak evidence for a 20 day flux varlation in the high state. Ra-anajysis of the Vela data with Finer time resolution can test the reality of this effect.

The Vela 5B X-ray experlment was deslgned and implemenced by $W . \quad D$. Evans, J. P. Conner, R. D. Bellan, J. A. Bergey, $H_{4}$ C. Owens, and $\mathrm{B}$. n. Tech of LOB Alamos, and the staff of Los Alamos National Laboratory. J. Terrell reduced the 10-year wass of dats to produce the 10-day akyraps. F. Cordova made useful comments on the manuscript. The work was performed under the ausplces of the $U$. $S$. Department of Energy.

\section{REPBRENCES}

Bonnet-B1daud, J. $M_{0}$, and van der K18, M. 1981,

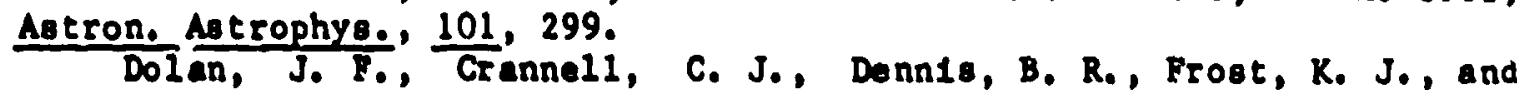
Orw\&8, L. B. 1982, Astrophys. Latt., 22, 147. Dowthwa1te, J. C. et al. 1983, Astron. Astrophys., 126, 1.

GrIndlay, J. E. 1982 , Proc. Internat Ional Workshop on H1gh Energy Game Ray Astron. (TIFR, Bombay), 178. kintwen, W. 1985, these procendinge.

Holt, S. S. et il. 1976, Netura, 260, 592.

Bolt, 8. 8., RelusienskI, L. J., Boldt, .. A., and Serlem1teos, P. J. 1979, Ap. J., 233, 344.

Lamb, R. C., Fichtel, C. B., Hartman, R, C., Kniffen, D. $A_{0}$, and Thompson, D. J. 1977, Ap. J. Lete., 212 , L63. 
Molten1, D., Rapisarda, M., Robba, N. R., and Scare1, L. 1980, Astron. Astrophys., 87, 88.

Par81gaault, D. $\bar{R}_{0}$ et al. 1972, Nature Phys. Sc1., 239, 123.

Prledhorsky, W. C., Terre11, J., and Holt, S. S., AP. J., 270, 233.

Swanenburg, B. N. et al. 1981, Ap. J. Lett., 243, L69.

Terrell, J., Peñmore, B. E., Klebesadel, R. W., and Desal,

U. D. 1982, Ap. J., 254, 279.

White, N. E., and Holt, S. S. 1982, Ap. J., 257, 318. 